\title{
PIJAT BAYI UNTUK MENINGKATKAN MOTORIK KASAR DUDUK DAN MERANGKAK MANDIRI PADA BAYI USIA 9 BULAN DI UPT KESMAS SUKAWATI I
}

\author{
Muji Murtiningsih, I Putu Darma Wijaya*, Agung Wahyu Permadi \\ Program Studi Fisioterapi Fakultas Ilmu Kesehatan Sains dan Teknologi,Universitas Dhyana Pura \\ Email: darmawijaya@undhirabali.ac.id
}

\begin{abstract}
ABSTRAK
Tumbuh kembang merupakan manifestasi yang kompleks dari perubahan morfologi, biokimia, dan fisiologi yang terjadi secara konsepsi sampai maturitas atau dewasa. Perkembangan (development) adalah perubahan yang bersifat kuantitatif dan kualitatif. Perkembangan motorik yang lambat dapat disebabkan oleh hal-hal tertentu seperti faktor keturunan dan faktor lingkungan. Stimulasi harus diberikan untuk mencegah adanya keterlambatan tumbuh kembang, stimulasi yang diberikan dalam penelitian ini adalah Taktil Stimulasi yaitu pijat bayi yang bermanfaat untuk meningkatkan motorik kasar bayi duduk dan merangkak mandiri.Rancangan dalam penelitian ini yang digunakan adalah rancangan one group pre test-post test design. Lokasi penelitian ini dilakukan di UPT.Kesmas Sukawati I, Gianyar. Analisis penelitian ini menggunakan uji wilcoxon. Hasil penelitian ini menunjukkan bahwa nilai yang diperoleh signifikan 0,000. Dengan demikian dapat disimpulkan bahwa pemberian pijat bayi dapat meningkatkan motorik kasar pada bayi.
\end{abstract}

Kata kunci : Perkembangan motorik kasar, Stimulasi, Pijat Bayi

\begin{abstract}
Growth and developmental system is a complex manifestation of morphologica, biochemical, and psycological changes that occur from the early stage of conception to the maturity or adulthood.Development is alteration process wich occured quantitatively and qualitatively. The poor motor skills development can caused by certain factors such as heredity and environtmental factor. Stimulation should be given to prevent delay in growth and development prosses, the stimulation wich given in this study is kind of tactile stimulation that is baby massage, wich is useful for improving the gross motor function of the baby sitting and crawling independently.The design of this study use one grup pre test-post design. The location of this study is conducted at UPT.Kesmas Sukawati I, Gianyar. These are 15 babies who participates in this study wich assessed having motor skills development is less than optimal. The analysis in this study is use wilcoxon test. The result of this studyindicates that there's any significantvalu 0.000. Thus, it can be concluded that the provision baby massage can increase gross motor in infants.
\end{abstract}

Keyword: Gross Motor skills development, Stimulation, Baby Massage

\section{PENDAHULUAN}

Tumbuh kembang merupakan manifestasi yang kompleks dari perubahan morfologi, biokimia, dan fisiologi yang terjadi secara konsepsi sampai maturitas atau dewasa. Istilah tumbuh kembang sebenarnya mencakup 2 peristiwa yang sifatnya berbeda tetapi saling berkaitan dan sulit dipisahkan, yaitu pertumbuhan dan perkembangan. Pertumbuhan (growth) adalah perubahan yang bersifat kuantitatif, yaitu bertambahnya jumlah, ukuran, dimensi pada tingkat sel, organ maupun individu. Perkembangan (development) adalah perubahan yang bersifat kuantitatif dan kualitatif. Perkembangan adalah bertambahnya kemampuan (skill) struktur dan fungsi tubuh yang lebih kompleks, dalam pola yang teratur, dan dapat diramalkan sebagai hasil dari proses pematangan atau maturitas.(Soetjiningsih, 2014).

Masa bayi merupakan tahapan dimana pertumbuhan dan perkembangan semakin cepat, dimulai dari bayi itu lahir sampai usia 1 tahun. Usia perkembangan bayi di bagi menjadi 2 yaitu: neonatus yaitu dari bayi mulai lahir sampai usia 28 hari dan disebut bayi mulai dari 29 hari sampai 12 bulan (World Health Organization, 2013)

Menurut Kemenkes RI, 2010 Pertumbuhan dan perkembangan masa bayi terbagi menjadi 4 bagian yaitu : usia $0-3$ bulan, $4-6$ bulan, $7-9$ bulan, dan $10-12$ bulan. Pada usia $4-6$ bulan dalam masa inilah tumbuh kembang anak lebih cepat perkembangan motoriknya. (Puspita, 2014)

Perkembangan motorik yang lambat dapat disebabkan oleh hal-hal tertentu seperti faktor keturunan dan faktor lingkungan. Faktor keturunan dimana pada keluarganya rata-rata perkembangan motorik lambat dan faktor lingkungan, seperti anak tidak diberi kesempatan untuk belajar karena terlalu dimanjakan, kurangnya stimulasi (sentuhan) selalu digendong atau diletakkan di babywalker terlalu lama dan juga anak yang mengalami 
deprivasi maternal. Disamping itu, faktor kepribadian anak misalnya: anak sangat penakut, gangguan retardasi mental juga adalah penyebab perkembangan motorik yang lambat (Soetjiningsih, 2012).

Stimulasi juga dibutuhkan di dalam proses tumbuh dan kembang, stimulasi ada beberapa yaitu stimulasi visual (penglihatan), verbal (berbicara), auditif (pendengaran), taktil (sentuhan), dapat mengoptimalkan perkembangan anak. Di dalam perkembangan motorik kasar perkembangan bayi usia 8 dan 9 bulan adalah mulai merangkak dan duduk secara mandiri, setelah melalui fase berguling secara mandiri. Seorang bayi tidak hanya ditentukan hanya bisa merangkak dan duduk saja tetapi kecepatan dan ketepatannya perlu diperhatikan, serta kemampuan perkembangan duduknya sesuai dengan usia bulannya atau tidak. Pengetahuan orang tua dalam memahami pentingnya stimulasi sejak dini sangatlah penting. Dengan orang tua memahami perkembangan anaknya dengan baik maka keterlambatan di dalam tumbuh kembang anakpun dapat di minimalisir. (Dewi Dkk,2015).

Dari hasil studi pendahuluan didapatkan bahwa pada empat sampel bayi yang diuji, ternyata tiga bayi mengalami keterlambatan tumbuh kembang, diuji dengan menggunakan Kuesioner Pra Skrining Perkembangan.

\section{METODE PENELITIAN}

\section{Jenis Penelitian}

Rancangan penelitian yang diterapkan pada penelitian ini menggunakan desain one group pretest and posttest design. Desain ini memiliki hasil sebelum dan sesudah diberikan perlakuan.

\section{Tempat dan Waktu penelitian}

Penelitian dilaksanakan di Penelitian dilakukan di UPT. Kesmas Sukawati I.

\section{Populasi dan Sampel Penelitian}

Populasi sampel dalam penelitian ini adalah bayi usia 9 bulan yang ada di Wilayah Kerja UPT Kesmas Sukawati I yang telah sesuai dengan kriterian inklusi dan eksklusi.

\section{Prosedur Penelitian}

a. Peneliti mempersiapkan sampel yang akan dijadikan subjek penelitian.

b. Peneliti membuat surat persetujuan yang harus ditanda tangani oleh orang tua, yang isinya bahwa subjek bersedia menjadi sampel penelitian sampai dengan selesai.

c. Peneliti memberikan edukasi kepada orang tua subjek yang akan diteliti, mengenai manfaat, tujuan, bagaimana penelitian ini dilakukan dan pentingnya penelitian ini dilakukan.

d. Peneliti melakukan pengukuran tumbuhn kembang bayi sebelum dan sudah diberikan perlakuan.

e. Dilakukan pijat bayi selama 3 minggu dan kemudian subjek diukur kembali dan hasil dari pengukuran sebelum dan sesudah diberikan perlakuan dibandingkan.

\section{Analisis Data}

Data yang diperoleh diuji normalitas menggunakan uji Wilcoxon yang bertujuan untuk mengetahui pijat bayi terhadap peningkatan motorik kasar duduk dan merangkak mandiri pada bayi usia 9 bulan di UPT.Kesmas Sukawati I.

\section{HASILDAN PEMBAHASAN}

\section{Hasil}

Perkembangan motorik sebelum dan sesudah diberikan pijat bayi. Pengukuran perkembangan motorik dilakukan pada 15 sampel penelitian sebelum diberikan pijat bayi (pretest) dengan menggunakan KPSP (Kuesioner Pra Skrining Perkem-bangan). Setelah diberikan pijat bayi dilakukan kembali pengukuran perkembangan motorik kepada 15 sampel penelitian (posttest) dengan menggunakan alat ukur KPSP (Kuesioner pra Skrining Perkem-bangan)

\section{Tabel 1}

Hasil pengukuran KPSP (Kuesioner Pra Skrining Perkembangan) pretest dan postest

\begin{tabular}{ccccc}
\hline \multirow{2}{*}{ Jawaban } & \multicolumn{2}{c}{ Pre Test } & \multicolumn{2}{c}{ Post Test } \\
\cline { 2 - 5 } & Nilai & Percent & Nilai & Percents \\
\cline { 2 - 5 } Ya & 86 & 57,3 & 117 & 78,0 \\
Tidak & 64 & 42,7 & 33 & 22,0
\end{tabular}

Dari hasil tabel di atas dapat disimpulkan bahwa terdapat selisih peningkatan perkembangan motorik pada setiap sampel penelitian. Presentasi kenaikan tertinggi yaitu $78 \%$ dari jawaban ya, dan presentasi terendah yaitu $22 \%$ dari jawaban tidak. Hal ini menunjukkan bahwa hasil pretest yang dilakukan 
mempunyai presentasi yang lebih kecil hasil posttest lebih besar dari hasil prestest. dibandingkan setelah diberikan pijat bayi, sehingga

Tabel 2

Uji normalitas

\begin{tabular}{ccc}
\hline \multirow{2}{*}{ Data } & \multicolumn{2}{c}{ Shapiro Wilk } \\
\cline { 2 - 3 } & $D f$ & $P$ \\
\hline Pre test & 150 & 0,000 \\
Post test & 150 & 0,000 \\
\hline
\end{tabular}

Berdasarkan tabel 2 didapat pretest perkembangan bayi usia 9 bulan adalah 0,000 $(\mathrm{p}<0,05)$ dan posttest adalah $0,000(\mathrm{p}<0,05)$ yang berarti tidak berdistribusi normal.

Tabel 3

Hasil Uji Wilcoxon

\begin{tabular}{cll}
\hline \multirow{2}{*}{ Data } & \multicolumn{2}{l}{ Wilcoxon } \\
\cline { 2 - 3 } & $\mathrm{Z}$ & $\mathrm{P}$ \\
\hline Pre-post & $-8,396$ & 0,000 \\
\hline
\end{tabular}

Untuk uji Wilcoxonpada pretest- posttest perkembangan bayi usia 9 bulan diperoleh nilai $\mathrm{z}$ hitung $\left(-8,396^{\mathrm{a}}\right)$ dan nilai $p(0,000)$. Hasil ini menunjukkan bahwa ada pengaruh yang signifikan pijat bayi terhadap peningkatan motorik kasar duduk dan merangkak mandiri pada bayi usia 9 bulan di UPT.Kesmas Sukawati I.

\section{PEMBAHASAN}

Pijat bayi adalah salah satu modalitas manual terapi untuk manipulasi manual pada jaringan lunak yang ditujukan untuk meningkatkan kesehatan bagi anak-anak. Tujuan dari pijat bayi ini adalah mengurangi rasa sakit, kecemasan, ketakutan atau stress pada anak anak yang membuat anak-anak merasa tidak nyaman dan cenderung rewel. Terapi pijat ini mempunyai peran penting di dalam perkembangan fisik, perkembangan kognitif dan merupakan salah satu upaya untuk pencegahan penyakit atau keterlambatan tumbuh kembang pada bayi. Pijat bayi juga merupakan perawatan komplementer yang dapat diberikan kepada bayi. Terapi ini telah dipraktekkan secara global dan semakin banyak digunakan di negara barat sebagai pengobatan untuk bayi, meskipun bukti ilmiah penggunaannya masih terbatas. Penelitian tentang efektifitas pijat bayi masih terus dilakukan, karena melihat keuntungan dari pijat bayi sangat menguntungkan seperti keterampilan anak didalam motorik kasar, motorik halus, dan pengembangan pshycomotor

Perkembangan motorik kasar merupakan gerakan fisik yang membutuhkan keseimbangan dan koordinasi antar anggota seluruh tubuh, dengan menggunakan otot-otot besar, sebagian atau seluruh anggota tubuh. Pada bayi usia 9 bulan ke atas otot-otot rangka sudah menguat sehingga bayi dapat melakukan gerakan motorik kasar tersebut. (Sulistyawati, 2014).

Bayi yang mendapatkan stimulasi terarah dan teratur seperti pijat bayi akan lebih cepat berkembang dibandingkan dengan bayi yang kurang atau tidak mendapat stimulasi. Karena pijat bayi dapat meningkatkan sirkulasi darah sehingga suplai oksigen ke seluruh tubuh dapat teratur. Selain itu, latihan juga dapat dapat meningkatkan stimulasi perkembangan otot dan pertumbuhan sel. Pijat bayi merupakan salah satu jenis stimulasi taktil. Stimulasi taktil adalah suatu jenis rangsangan sensori yang paling penting untuk perkembangan bayi yang optimal (Roesli, 2006). Hasil penelitian ini dimungkinkan berkaitan pada gerakan pijat bayi didaerah punggung dimana bayi pada posisi duduk membutuhkan otot-otot punggung yang kuat untuk mempertahankan posisinya saat duduk tegak mandiri, berkaitan juga dengan gerakan bayi pada daerah tangan yang menguatkan otot-otot pada lengan bayi sehingga bayi dapat menopang badan saat dalam posisi merangkak.

Hasil dari penelitian ini khususnya gross motorik ini hampir senada dengan penelitian yang dilakukan oleh Puspita Eka Kurnia Sari (2014), yang menyatakan bahwa pemberian pijat bayi dapat meningkatkan pertumbuhan dan perkembangan bayi khususnya motorik kasar 
tengkurap. Hasil penelitian ini juga sesuai dengan riset yang dilakukan oleh Inal dan Yildiz (2012) yang membuktikan bahwa bayi yang mendapatkan pijat bayi sedini mungkin akan mendapatkan perkembangan yang lebih cepat dibandingkan dengan bayi yang tidak diberikan pijatan.

Hormon pertumbuhan (growth hormone) yang mempengaruhi pertumbuhan tulang pada bayi dapat dirangsang dengan pijat bayi yang diberikan menyebabkan diskresikannya serotonin. Dalam fisiologi pijat bayi disebutkan bahwa serotonin yang disekresikan oleh sistem saraf dalam hipotalamus akan meningkatkan kecepatan sekresi hormon pertumbuhan yang pada akhirnya akan meningkatkan pertumbuhan bayi termasuk tulang (Warner,2004).

\section{KESIMPULAN}

Berdasarkan hasil penelitian dapat disimpulkan pijat bayi dapat meningkatkan motorik kasar duduk dan merangkak mandiri pada bayi usia 9 bulan di UPT.Kesmas Sukawati I.

\section{DAFTAR PUSTAKA}

Curat, Dr., 2017. Pediatric Massage. last edited on 21 june 2017 at 20.03 .

Dewi, C.R dkk., 2015. Teori dan Konsep Tumbuh Kembang Bayi Toolder, Anak dan Usia Remaja. Medical Book

Dhamayanti, Meita., 2006. Kuesioner Pra Skrining Perkembangan (KPSP) Anak. Sari Pediatri Vol.8.

Dewi, C.R dkk., 2015. Teori dan Konsep Tumbuh Kembang Bayi Toolder, Anak dan Usia Remaja. Medical Book

Puspita, S. E. K., 2014. Efektifitas Pijat Bayi terhadap Pertumbuhan dan Perkembangan bayi usia 6 bulan. UIN Naskah Publikasi

Roesli, U., 2006.Pedoman Pijat Bayi. Ed.revisi cetakan 1

Soetjiningsih., 2012. Tumbuh Kembang Anak, Ed.1. EGC, Jakarta

Soetjiningsih., 2014. Tumbuh Kembang Anak, Ed.II.Jakarta : EGC

Sulistyawati, Ari., 2014. Deteksi Tumbuh Kembang Anak.Jakarta: Salemba Medika

Warner, Penny. Perkembangan Bayi Minggu per Minggu pada Tahun Pertama. Jakarta : Arcan 2004. Judul Asli Smart Start your Baby : your baby's development week by week during the first year and how you can help

World Health Organization., 2013. Health Topic : Infant, Newborn, Geneva:W 
Murtiningsih.M.,Wijaya.I.P.D.,Permadi.A.W / Kesehatan Terpadu 3(1) (2019) 
Murtiningsih.M.,Wijaya.I.P.D.,Permadi.A.W / Kesehatan Terpadu 3(1) (2019) 